\title{
Free Nocardomycolic Acids in the Classification of Nocardias and Strains of the 'Rhodochrous' Complex
}

\author{
By M. GOODFELLOW, D. E. MINNIKIN AND P. V. PATEL \\ Department of Microbiology and School of Chemistry, \\ The University of Newcastle upon Tyne, Newcastle upon Tyne, NEI $7_{R U}$ \\ AND HALINA MORDARSKA \\ Institute of Immunology and Experimental Therapy, \\ Polish Academy of Sciences, Wroclaw, Poland
}

(Received I3 June 1972; revised 7 August 1972)

INTRODUCTION

Good characters are at a premium in taxonomy, especially where classification is confused and complex. Chemotaxonomic characters are being increasingly used and have been partly responsible for improvements in the classification of actinomycetes (Lechevalier, Lechevalier \& Gerber, I97I). The analyses of lipid fractions have been found to be particularly useful in separating strains of Nocardia and Mycobacterium. These taxa contain $\beta$-hydroxy-acids of high molecular weight which have a long chain in the $\alpha$-position and are collectively called mycolic acids. The mycobacteria produce a wide range of mycolic acids which may contain methyl branches and oxygen functions (oxo, methoxy and carboxy) other than the $\beta$-hydroxy-acid system. The mycolic acids of nocardias, termed nocardomycolic acids, are less complicated and consist mainly of long chains containing a varying number of cis-unsaturated linkages (Michel, Bordet \& Lederer, 1960). The structures of the nocardomycolic acids of Nocardia asteroides ATcC 9969 as determined by Bordet, Etémadi, Michel \& Lederer (I965) are given:

$$
\begin{aligned}
& \mathrm{CH}_{3} \cdot\left(\mathrm{CH}_{2}\right)_{7} \cdot \mathrm{CH}=\mathrm{CH} .\left(\mathrm{CH}_{2}\right)_{x} \cdot \mathrm{CH}=\mathrm{CH} .\left(\mathrm{CH}_{2}\right)_{y} \cdot \mathrm{CH}=\mathrm{CH} \cdot\left(\mathrm{CH}_{2}\right)_{z} \cdot \mathrm{CHOH} \cdot \mathrm{CH} \cdot \mathrm{COOH} \\
& \text { cis cis cis } \\
& x+y+z=\mathrm{I} 5, \mathrm{I} 7,19,2 \mathrm{I} \text {. }
\end{aligned}
$$

$$
\begin{aligned}
& \mathrm{CH}_{3} \cdot\left(\mathrm{CH}_{2}\right)_{7} \cdot \mathrm{CH}=\mathrm{CH} .\left(\mathrm{CH}_{2}\right)_{x} \cdot \mathrm{CH}=\mathrm{CH} .\left(\mathrm{CH}_{2}\right)_{y} \cdot \mathrm{CHOH} . \mathrm{CH} \cdot \mathrm{COOH} \\
& x+y=23,25,29 .
\end{aligned}
$$

Acids of this general type occur invariably as mixtures of homologues; more detailed analyses of the nocardomycolates of Nocardia asteroides (Bordet \& Michel, 1969) and other species of Nocardia (Maurice, Vacheron \& Michel, 1971) have been made.

Methyl esters of mycolic acids on pyrolysis produce a meromycolic aldehyde and a straight-chain ester.

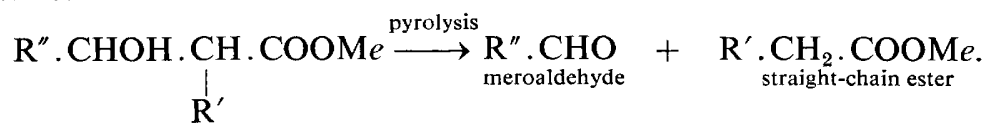


The straight-chain esters derived from nocardomycolic esters can be distinguished from those of the true mycolates by their shorter chain length. The detection of these differences in structure using either mass spectrometry (Etémadi, 1967) or pyrolysis gas chromatography (Lechevalier, Horan \& Lechevalier, I97I) provides a means of distinguishing between mycobacteria and nocardias.

Mordarska (I968) and Mordarska \& Mordarski (I969) analysed lipids by means of thin-layer chromatography (t.l.c.) and found a component which appeared to be specific for nocardias. This lipid was subsequently called lipid characteristic of Nocardia or LCN-A (Mordarska \& Réthy, 1970) and its detection provided a reliable way of distinguishing nocardias and 'rhodochrous' strains from other nocardioform bacteria (Mordarska, Mordarski \& Goodfellow, I972). This report presents evidence to show that the lipid LCN-A's are free nocardomycolic acids.

\section{RESULTS}

Nocardia caviae NCTC I 934 and a representative of the 'rhodochrous' complex (Nocardia calcarea $\mathrm{NCIB} 8863$ ) were grown in modified Sauton's medium, tested for purity, harvested, dried and the lipids extracted with ethanol:diethyl ether (I:I), as described previously by Mordarska et al. (1972). The partially extracted cells of $N$. caviae and the 'rhodochrous' strain were exhaustively extracted with chloroform and the residue hydrolysed by heating under reflux with $2.5 \mathrm{~N}$-methanolic $\mathrm{KOH}$ in benzene for $6 \mathrm{~h}$. The hydrolysate was neutralized with dilute $\mathrm{HCl}$ and extracted with diethyl ether; evaporation of the ethereal extract gave a wax which consisted mainly of nocardomycolic acid (Ioneda, Lederer \& Rozanis, I970).

Thin-layer chromatograms (Merck silica gel PF 254+366) were, in all cases, developed with hexane: diethyl ether:acetic acid (80:20:I, by vol.). The ethanol-ether extracts of both strains contained a component having the main characteristic of LCN-A lipids in that no migration was observed when the chromatogram was redeveloped in methanol (Mordarska et al. 1972). The nocardomycolic acids from each strain showed identical chromatographic behaviour to the LCN-A lipid of the corresponding strain. As previously noted (Mordarska et al. 1972), the LCN-A lipid and nocardomycolic acid from Nocardia caviae had a slightly greater chromatographic mobility $\left(R_{F} O \cdot I 8\right)$ than the corresponding components from the 'rhodochrous' strain $\left(R_{F} 0 \cdot 14\right)$.

Nocardomycolic acids and LCN-A lipids were isolated by preparative t.l.c. and esterified with ethereal diazomethane. The methyl esters of the nocardomycolic acid and LCN-A of Nocardia caviae had $R_{F} 0.55$ on t.l.c. and those from the 'rhodochrous' strain had $R_{F} 0.48$; the difference in mobility was thus maintained after esterification.

Pyrolysis gas chromatography (Perkin-Elmer F I I, $2 \mathrm{~m} \times 3 \mathrm{~mm}$ column of $2 \frac{1}{2} \% \mathrm{OV}-\mathrm{I}$ on Chromsorb $\mathrm{G}$ at $200^{\circ} \mathrm{C}$, inlet $270^{\circ} \mathrm{C}, \mathrm{N}_{2}$ as carrier gas) of the methyl esters of LCN-A and nocardomycolic acid from Nocardia caviae released methyl esters of straight-chain acids having 14 and 16 carbon atoms; esters of acids having 12 , I4 and 16 carbons were released from the corresponding esters of the 'rhodochrous' strain. Mass spectrometry (A.E.I., MS 9) of these esters confirmed the release of straight-chain esters (peaks at $m / e 214,242$ and 270 ) as determined by gas chromatography. 


\section{DISCUSSION}

The chromatographic and spectral behaviour of the methyl esters of the lipid LCN-A and nocardomycolic acid from Nocardia caviae are practically identical, as are those from the 'rhodochrous' strain. These results show that the so-called LCN-A lipids characteristic for Nocardia have properties consistent with those of free nocardomycolic acids. The results obtained lead to the partial structure

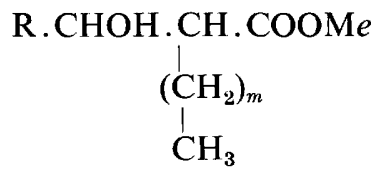

for the nocardomycolates of $N$. caviae ( $m=$ II, I3), and for the 'rhodochrous' strain $(m=9$, II, I3). An explanation of why the nocardomycolates of the latter have a lower mobility than those of $N$. caviae must await findings from additional studies on the chemical structure of these molecules. The results explain the characteristic immobility of lipid LCN-A on t.l.c. when using methanol as eluant, since nocardomycolic acids are insoluble in methanol.

The results also explain the basis of the technique used to detect lipid LCN-A (Mordarska et al. 1972) and why this method can be confidently used to distinguish nocardias and strains of the 'rhodochrous' complex from allied taxa. Thus the nocardomycolates have a comparatively low molecular weight (40 to 60 carbon atoms) and are soluble in ethanolether (I:I), whereas the mycolates from mycobacteria have a higher molecular range ( 80 to 90 carbon atoms) and can be extracted with chloroform but are insoluble in such ethanol-ether mixtures.

The relative insolubility of the mycolic acids of mycobacteria in ethanol-ether mixtures forms the basis of a simple chemical method used to distinguish Mycobacterium from Nocardia (Kanetsuna \& Bartoli, I972). In this method bacteria are saponified and the ethereal extract treated with an equal volume of ethanol. Mycobacteria give a heavy precipitate of mycolic acids (melting point 45 to $70^{\circ} \mathrm{C}$ ) while nocardias form either no precipitate or only tiny amounts which have a much higher melting point. This method is therefore a reliable way of distinguishing mycobacteria from strains of allied taxa.

The procedure reported here requires no sophisticated equipment and does not involve the chemical transformations which are necessary in the mycolic ester pyrolysis method of Lechevalier et al. (1971) and in the mycolic acid precipitation technique of Kanetsuna \& Bartoli (1972). The latter technique is only capable of distinguishing mycobacteria from other organisms; the present procedure gives a positive reaction only with nocardias and 'rhodochrous' strains and is, therefore, complementary. As a confirmatory procedure the LCN-A or mycolic acid precipitate of Kanetsuna \& Bartoli (1972) might be esterified and its identity checked by the gas chromatographic technique of Lechevalier et al. (I97I) or by other physical and chemical procedures.

We thank Grace Hedley for maintaining cultures and preparing cells and P. Kelly for mass spectrometry. One of us, M.G., thanks the Medical Research Council for support (Grant G 970/I I2/B). 


\section{REFERENCES}

Bordet, C. \& Michel, G. (1969). Structure et biogenèse des lipides à haut poids moléculaire de Nocardia asteroides. Bulletin de la Société de chimie biologique 51, 527-548.

Bordet, C., Etémadi, A. H., Michel, G. \& Lederer, E. (1965). Structure des acides nocardiques de Nocardia asteroides. Bulletin de la Société chimique de France 234-235.

ETÉmADI, A. H. (1967). The use of pyrolysis gas chromatography and mass spectroscopy in the study of the structure of mycolic acids. Journal of Gas Chromatography 5, 447-456.

IONEDA, T., Lederer, E. \& Rozanis, J. (1970). Sur la structure des diesters de tréhalose ('cord factors') produits par Nocardia asteroides et Nocardia rhodochrous. Chemistry and Physics of Lipids 4, 379-392.

Kanetsuna, F. \& Bartoli, A. (1972). A simple chemical method to differentiate Mycobacterium from Nocardia. Journal of General Microbiology 70, 209-2 12.

Lechevalier, M. P., Horan, A. C. \& Lechevalier, H. (I97I). Lipid composition in the classification of nocardiae and mycobacteria. Journal of Bacteriology 105, 3I3-318.

Lechevalier, H. A., Lechevalier, M. P. \& Gerber, N. N. (1971). Chemical composition as a criterion in the classification of actinomycetes. Advances in Applied Microbiology 14, 47-72.

Maurice, M. T., Vacheron, M.J. \& Michel, G. (I97I). Isolement d'acides nocardiques de plusieurs espèces de Nocardia. Chemistry and Physics of Lipids 7, 9-18.

Michel, G., Bordet, C. \& Lederer, E. (1960). Isolément d'un nouvel acide mycolique: l'acide nocardique à partir d'une souche de Nocardia asteroides. Compte rendu de l'Académie des sciences 250, 35I 8-3520.

Mordarska, H. (1968). A trial of using lipids for the classification of actinomyctes. Archivum immunologiae et therapiae experimentalis $16,45-50$.

MordarsKa, H. \& Mordarski, M. (I969). Comparative studies on the occurrence of lipid A, diaminopimelic acid and arabinose in Nocardia cells. Archivum immunologiae et therapiae experimentalis 17, 739-743.

Mordarska, H. \& RÉTHY, A. (1970). Preliminary studies on the chemical character of the lipid fraction in Nocardia. Archivum immunologiae et therapiae experimentalis $18,455-459$.

Mordarska, H., Mordarski, M. \& Goodfellow, M. (1972). Chemotaxonomic characters and classification of some nocardioform bacteria. Journal of General Microbiology 71, 77-86. 